\title{
Fortified protein rich soya product "Nutrameal - Shakti Aahar" and its sensory, nutritional and microbiological analysis
}

\author{
MAMTA TIWARI, KHUSHBOO GUPTA AND GUNJAN SANADYA
}

Received: 14.07.2017; Revised: 06.11.2017; Accepted: 21.11.2017

See end of the paper for authors' affiliations MAMTA TIWARI

Directorate of Prioritization, Monitoring and Evaluation, Agriculture University, KOTA (RAJASTHAN) INDIA

Email : mamtatewari63@

gmail.com
ABSTRACT : Soybean contains high amount of protein, dietary fibre and polyunsaturated fatty acids and has numerous therapeutic benefits. Due to its health beneficial properties it was incorporated with other ingredients and turned into sattu and a new product Nutrameal - Shakti Aahar, formulated in this endeavour. Prepared Nutrameal - Shakti Aahar (both sweet as well as salted) was subjected to sensory analysis. Estimation of moisture, protein, fat, carbohydrate, calcium and iron was done. Microbial load of fresh Nutrameal - Shakti Aahar sample was assessed. Both sweet and salted Nutrameal - Shakti Aahar was liked by the experts. Its appearance, colour and overall acceptability were liked moderately (scores 7.0) by the panel members. Both type of Nutrameal - Shakti Aahar were highly nutritive. They were excellent source of protein and contained sufficient amount of carbohydrate and fat. Microbial content was with in limits, hence, products were safe to consume. Level of fatigue was decreased with regular intake of sweet Nutrameal Shakti Aahar. Weight gain and efficiency level of rural women was enhanced with its consumption. It can be concluded that the products were tasty, healthy, safe to use and low in cost thus can be a part of daily diet of individual, without changing their regular dietary consumption.

KEY WORDS: Fortified protein, Soya product, Nutrameal-Shakti Aahar, Sensory, Nutritional analysis, Microbiological analysis

- HOW TO CITE THIS PAPER : Tiwari, Mamta, Gupta, Khushboo and Sanadya, Gunjan (2017). Fortified protein rich soya product "Nutrameal - Shakti Aahar" and its sensory, nutritional and microbiological analysis. Asian J. Home Sci., 12 (2) : 592-596, DOI: 10.15740/HAS/AJHS/12.2/592-596. 